\title{
Epidemiologic Analysis of Urological Cases Admitted to an Emergency Department of a Tertiary Care Center
}

\author{
Üçüncü Basamak Sağlık Merkezinin Acil Servisine Başvuran Ürolojik Olguların \\ Epidemiyolojik Analizi
}

\author{
(D) Reha Girgin, (D) Kamil Erdem \\ Zonguldak Bülent Ecevit University Faculty of Medicine, Department of Urology, Zonguldak, Türkiye
}

\section{What's known on the subject? and What does the study add?}

Emergency physicians should be familiar with simple urological interventions that are vital for patients. Such epidemiological studies can help us determine with which subjects we should be more sensitive during medical intervention.

\begin{abstract}
Objective: We evaluated emergency urology patients admitted to the emergency department of our hospital in terms of demographic and epidemiological characteristics, in order to contribute to the relevant data of our country.

Materials and Methods: Of 362,139 patients, the demographic characteristics, established diagnoses, treatments, and results of 1409 emergency urology patients, who were admitted to Zonguldak Bülent Ecevit University Faculty of Medicine, Hospital's Emergency Department between January 2012 and December 2018, were analyzed retrospectively.

Results: Of the 362,139 patients admitted to the emergency department, 1409 (0.39\%) were emergency urology patients. 69.9\% of the patients were male (mean age: 57 ), and $30.1 \%$ of them were female (mean age: 54 ). The most frequent illness was renal colic constituting $25.5 \%$ of the cases followed by massive macroscopic hematuria (20.7\%). Among the emergency urology patients, 381 (15.5\%) underwent surgical procedures. The most performed procedure was for treating urethral stricture, which required urological expertise.

Conclusion: While some of the emergencies can be diagnosed using simple methods and most urological emergencies can be managed with simple interventions, urologists' intervention may be needed quickly if necessary. All emergency physicians should be aware of these simple approaches that otherwise may have severe consequences for patients.
\end{abstract}

Keywords: Emergency, Epidemiology, Urological cases

Öz

Amaç: Hastanemiz acil servisine başvuran ürolojik acil olguların demografik ve epidemiyolojik özellikleri açısından değerlendirerek, ülkemiz güncel verilerini gözden geçirmektir.

Gereç ve Yöntem: Zonguldak Bülent Ecevit Üniversitesi Hastanesi Acil Servisine Ocak 2012 - Aralık 2018 tarihleri arasında başvuran 362.139 hasta içinden 1409 ürolojik olgunun demografik özellikleri, teşhis, tedavi ve sonuçları retrospektif olarak incelendi.

Bulgular: 362.139 acil olgudan 1409'u $(\% 0,39)$ ürolojik acil durumludur. Olguların \%69,9'u erkekti (yaş ortalaması: 57) ve \%30,1'i kadındı (yaş ortalaması: 54). En sık görülen olgu masif makroskopik hematüri $(\% 20,7)$ ve ikinci en sık olgu \%25,5 ile renal kolikti. Ürolojik acil olgular için 381 $(\% 15,5)$ cerrahi müdahale gerçekleştirildi. En sık uygulanan işlem ürolojik uzmanlık gerektiren üretral darlık içindi.

Sonuç: Çoğu ürolojik acil durum basit müdahalelerle düzeltilebilir ve öte yandan, bazı acil durumların ise basit yöntemlerle tanısı konabilir; ancak gerektiğinde hızlı bir şekilde üroloji uzmanı müdahalesine ihtiyaç duyulabilir. Tüm acil servis doktorları, uygulanmadığında hastalar için ciddi sonuçlar doğurabilecek bu basit yaklaşımların farkında olmalıdır.

Anahtar Kelimeler: Acil, Epidemiyoloji, Ürolojik olgu

Correspondence: Reha Girgin MD, Zonguldak Bülent Ecevit University Faculty of Medicine, Department of Urology, Zonguldak, Türkiye Phone: +90 5378865912 E-mail: mujdereha@hotmail.com ORCID-ID: orcid.org/0000-0003-1132-8629

Received: 15.11.2019 Accepted: 20.01.2020

Cite this article as: Girgin R, Erdem K. Epidemiologic Analysis of Urological Cases Admitted to an Emergency Department of a Tertiary Care Center. J Urol Surg 2020;7(3):227-231.

${ }^{\circ}$ Copyright 2020 by the Association of Urological Surgery / Journal of Urological Surgery published by Galenos Publishing House. 


\section{Introduction}

Emergency departments are the most important unit of the hospitals which are available 24 hours a day, 7 days a week, and where patients are evaluated quickly after determining the appropriate triage level (1). Urological emergencies can be overlooked by emergency services' specialists as they constitute only a small proportion of patients presenting to the emergency department (1). A significant proportion of urological emergency cases admitted to the hospitals are considered acute cases and require rapid intervention (2). When the patients are evaluated in the emergency department, it may be necessary to seek a urologist's opinion. However, in the absence of urologists, emergency physicians should be able to handle these conditions. Urological emergencies may occur due to accidents, as well as iatrogenic causes, stones, infections, or tumoral events (3). Urological emergencies, which can easily be overlooked in all emergency cases, should be carefully and systematically evaluated. Urological emergencies seen in the emergency departments can be listed as acute renal colic, massive hematuria, acute urinary retention, acute scrotal diseases, priapism, urinary tract infections (UTIs), and genitourinary traumas (4). In our country, several epidemiological studies have been conducted to cover urological emergencies $(1,5)$. In order to contribute to the relevant data of our country, we evaluated patients with urological emergencies admitted to the emergency department of our hospital in terms of demographic and epidemiological characteristics.

\section{Material and Methods}

Ethical approval was obtained from the local ethic committee (protocol number: 2019-203-18/2). Of 362,139 patients, the data of 1409 emergency urology patients, who were admitted to Zonguldak Bulent Ecevit University Hospital's Emergency Department between January 2012 and December 2018, were analyzed retrospectively. A written informed consent was obtained from the patients. The medical files of the so-called urological emergencies were retrieved from the hospital's database, and the demographic characteristics, established diagnoses, treatments and results of the urological emergency cases were analyzed. $12.8 \%$ of the emergency cases were elective cases that actually did not require emergency evaluation.

The patients admitted to the emergency department were first evaluated by the emergency department assistant and specialist and then, if deemed necessary, were evaluated by the urology assistant and specialist. Cases with suspected genitourinary infections were evaluated by complete blood count and urinalysis and urine culture when necessary. In patients with renal colic complaints, complete urine analysis, kidney-urethra- bladder radiograms, and urinary ultrasound were performed. Noncontrast spiral computed tomography of the whole abdomen was requested in patients with urinary stone disease or a history of stones. Color Doppler ultrasonografi of the scrotum was requested in patients with penoscrotal traumas and acute scrotal pathologies. Direct radiographs (cystography, urethrography, etc) with contrast were requested for all patients with suspected urethral and bladder traumas. In patients where the upper urinary tract may be affected, contrast-enhanced abdominal tomography was requested. Patients with visible hemorrhage in the urine were diagnosed as having macroscopic hematuria, and patients with impaired micturition and hemodynamic stability were diagnosed as having massive hematuria.

\section{Statistical Analysis}

Statistical analysis were performed using SPSS 19.0 software (SPSS Inc., Chicago, IL, USA). Descriptive statistics were expressed as frequency and percent. Continuous variables were expressed as median (minimum-maximum).

\section{Results}

A total of 1409 patients with urological emergencies were evaluated in the emergency department. $69.9 \%(n=985)$ of the patients were male and $30.1 \%(n=424)$ were female. The mean age of male patients was 57 (2-298) years and 54 (1-96) years for female patients, respectively. $7.2 \%(n=101)$ of the patients were younger than 16 years and $46.2 \%(n=651)$ were older than 65 years. The distribution of the clinical diagnoses of urological cases admitted to the emergency department is given in Table 1. Subclass diagnoses of trauma and acute scrotum cases were shown in Tables 2 and 3. Genitourinary infection was found in $5.8 \%(n=89)$ of the patients, $56.2 \%(n=50)$ of which were female and $43.8 \%(n=39)$ were male. $21.3 \%(n=19)$ of the

Table 1. Distribution of clinical diagnoses of urological emergencies

\begin{tabular}{|l|l|l|}
\hline Diagnosis & Patients, $\mathbf{~}$ & \% \\
\hline Acute renal colic & 359 & 25.5 \\
\hline Massive macroscopic hematuria & 292 & 20.7 \\
\hline Genitourinary system traumas & 165 & 11.7 \\
\hline Acute urinary retention & 150 & 10.6 \\
\hline Acute scrotum & 115 & 8.2 \\
\hline Genitourinary system infections & 89 & 6.3 \\
\hline Priapism & 23 & 1.6 \\
\hline Scrotal abscess & 13 & 0.9 \\
\hline Fournier's gangrene & 13 & 0.9 \\
\hline Penile fracture & 9 & 0.6 \\
\hline Elective cases & 181 & 12.8 \\
\hline Total & $\mathbf{1 4 0 9}$ & $\mathbf{1 0 0}$ \\
\hline & &
\end{tabular}




\begin{tabular}{|l|l|l|}
\hline Table 2. Distribution of trauma cases \\
\hline Diagnosis & Patients, $\mathbf{~}$ & $\%$ \\
\hline Minor renal trauma & 50 & 30.3 \\
\hline Penile and scrotal injuries & 49 & 29.7 \\
\hline Major renal injury & 25 & 15.2 \\
\hline Urethral injuries & 15 & 9.1 \\
\hline Ureteral injury & 15 & 9.1 \\
\hline Bladder injury & 11 & 6.7 \\
\hline Total & 165 & 100 \\
\hline
\end{tabular}

Table 3. Distribution of acute scrotum cases

\begin{tabular}{|l|l|l|}
\hline Diagnosis & Patients, $\mathbf{n}$ & $\mathbf{\%}$ \\
\hline Epididymo-orchitis & 42 & 35 \\
\hline Penoscrotal edema & 42 & 35 \\
\hline Testicular torsion & 20 & 16.7 \\
\hline Torsion of the appendix testis & 10 & 8.3 \\
\hline Testicular mass & 6 & 5 \\
\hline Total & $\mathbf{1 2 0}$ & $\mathbf{1 0 0}$ \\
\hline
\end{tabular}

patients were hospitalized for treatment. Acute renal colic was diagnosed in 23.6\% ( $n=359)$ of the patients. $44 \%(n=158)$ of the patients were male, $56 \%(n=201)$ were female, and 65 (18.1\%) were hospitalized for treatment. Of the 150 (9.9\%) patients diagnosed with acute urinary retention, 133 were male patients (88.7\%) while female patients were 17 (11.3\%). Twenty-eight patients (18.7\%) were hospitalized and treated. Percutaneous cystostomy catheter was inserted in $4.7 \%(n=7)$ of the patients admitted to the emergency department due to urinary retention. Of the 292 (19.2\%) patients with macroscopic hematuria, 30.8\% ( $n=90)$ were hospitalized and treated. 20.6\% $(n=37)$ of the patients who were evaluated due to genitourinary system trauma were multitrauma cases. $26.1 \%(n=43)$ of the patients had renal trauma, all of which were hospitalized. Four of the major renal trauma cases were explored, and three patients underwent nephrectomy. Suprapubic cystostomy catheters were inserted in 3 of 15 patients with urethral trauma diagnosed by urethrography. Urethral catheters were placed in seven patients by a urologist, and the other patients were catheterized via the urethral route by the emergency specialists. Testicular torsion was diagnosed in 20 of the patients who had a preliminary diagnosis of acute scrotum. Seventeen patients underwent surgical detorsion, and one patient underwent manual detorsion. Two patients required orchectomy.

A total of $1028(72.6 \%)$ patients were treated using simple interventions without the need for hospitalization. Detailed information about the type of the surgical treatment needed for patients is given in Table 4. During this period, none of the patients needed referral to another center.
Table 4. Distribution of the patients who had undergone surgical interventions

\begin{tabular}{|l|l|l|}
\hline Diagnosis & Patients, $\mathbf{~}$ & \% \\
\hline $\begin{array}{l}\text { Opening of urethral stricture/using guide/ } \\
\text { requiring expertise }\end{array}$ & 95 & 24.9 \\
\hline Clot evacuation, and bladder irrigation & 78 & 20.5 \\
\hline Double-J catheter insertion & 67 & 17.6 \\
\hline Testicular detorsion and/or fixation & 20 & 5.2 \\
\hline Renal exploration & 20 & 5.2 \\
\hline Percutaneous cystostomy & 19 & 4.9 \\
\hline Debridement of Fournier's gangrene & 13 & 3.4 \\
\hline Drainage of the scrotal abscess & 13 & 3.4 \\
\hline Priapism (distal shunts) & 13 & 3.4 \\
\hline Orchiectomy & 10 & 2.6 \\
\hline Repair of penile fracture & 9 & 2.4 \\
\hline Repair of scrotal cuts & 7 & 1.8 \\
\hline Repair of bladder rupture & 5 & 1.3 \\
\hline Urethral stone extraction & 2 & 0.5 \\
\hline Total & $\mathbf{3 8 1}$ & $\mathbf{1 0 0}$ \\
\hline
\end{tabular}

\section{Discussion}

The emergency department is the unit where rapid interventions are performed and multidisciplinary approaches are applied from time to time. In general, urological cases requiring emergency intervention are less common than other cases. Acute renal colic, genitourinary infections, urinary retention, genitourinary trauma, acute scrotal and penile pathologies, and gross hematuria are the main urological emergencies (6). In our country, the statistical data related to urological emergency cases presenting to the emergency services vary greatly.

UTIs are the most encountered in urological practice. Almost $50 \%$ of the population experience UTls at least once in their lifetime (7). Although various risk factors increase the probability of developing UTIs, it is especially more common in females (8). Uncomplicated infections respond to medical treatment, whereas complicated cases require inpatient treatment. In our study, 5.8\% of the patients admitted to the emergency department had genitourinary system infections, where 56.2\% of the patients were females and $21.3 \%$ were hospitalized for treatment. The rates in our study were lower than those in the literature $(1,5,9)$. We believe that this may be due to low patient rates.

Renal colic is a condition that $1 \%-10 \%$ of the people may experience in their lifetime (10). Renal colic pain is an important complaint that urges patients with a history of renal stones to go to the emergency department (10). On searching the literature, it was found that renal colic attacks, seen especially among men, make up only $1 \%$ of emergency admissions $(2,11)$. 
In Europe, 8\% of the first-aid emergency ambulance service calls are because of acute renal colics (12). Topaktas et al. (1) reported that renal colic is the second most common case. In another study, Akıncı (5) reported a similar rate of renal colic as the second most common case. In our study, however, renal colic cases were the leading cause for emergency admissions. Again, unlike the literature, the dominant gender among these patients was female. This high rate reflects the incidence of urinary stone disease in our region in particular.

The risk of acute urinary retention, an important cause of emergency admissions, increases with age (5). Acute urinary retention is treated using catheterization (5). The first choice and less invasive option is urethral catheter insertion. This procedure can be done by emergency doctors. However, in cases such as benign prostatic hyperplasia, urethral trauma, urethral strictures, and foreign body in urethra which may cause difficulties in catheterization, interventions requiring urological expertise or percutaneous cystostomy may be warranted (2). In a study by Fall et al. (13), the incidence of suprapubic cystostomy insertion was $59.8 \%$, compared to $22.3 \%$ in the study by Topaktas et al. (1). In our study, urethral catheter insertion rate requiring urology expertise was found to be $24.9 \%$, while this rate was $4.89 \%$ for percutaneous cystostomy.

The incidence of hematuria has been reported in the literature between 4\% and 20\% (14). Macroscopic hematuria is defined as the presence of a noticeable amount of blood in the urine, which has a major cause (15). Massive hematuria is a more severe form of macroscopic hematuria and may cause acute urinary retention due to clot development in the patients (16). Although macroscopic hematuria occur for many reasons, it is important to evaluate the patient's vital signs and clot retention in the emergency department. If retention developed due to clot in emergency conditions, it should be evacuated manually with the help of a urethral catheter or using endoscopic methods. In our study, irrigation was applied to 78 of the patients who presented to the emergency department with massive hematuria. Of these, 10 patients required endoscopic intervention.

Acute scrotum is characterized by scrotal pain, tenderness, and swelling. Different pathologies may cause acute scrotum. While infective causes are in the foreground, testicular torsion, which should be diagnosed, and managed in a short time, constitutes the most urgent pathology. 30\% of patients with acute scrotum experience testicular torsion, and in this study, it was $17.4 \%$. Orchectomy was performed in four (20\%) patients.

10\%-15\% of traumas include the genitourinary system $(1,5)$. These are mostly blunt traumas (17). The kidneys are the most affected organ (9). Although ureteral injury is rare, it is mostly iatrogenic (18). Pelvic fractures may also be involved in bladder and urethral injuries (1). Penis and scrotal injuries are relatively less common (1). In our study, the most common genitourinary trauma was kidney injuries (48\%). Less than $10 \%$ of renal traumas require surgical intervention (19). Renal exploration was needed in $26.6 \%$ of our patients, and nephrectomy was required only in one $(1.3 \%)$ patient.

Priapism is a condition that needs to be evaluated and managed rapidly in order to maintain the erectile function. Ten of 23 patients with priapism responded to penile aspiration and irrigation treatment. The remaining 13 patients underwent distal shunt technique. However, the technique was not sufficient in three patients.

Scrotal abscess and Fournier's gangrene are very rare conditions that can have serious consequences when emergency interventions are not performed (20). In this study, 13 patients had scrotal abscesses. They were treated successfully with drainage. In seven of 13 patients with Fournier's gangrene, the departments of anesthesia, general surgery, and plastic reconstructive surgery were involved. In four of the seven patients, the departments of anesthesia and plastic surgery were involved and in two patients only the anesthesia department was involved.

\section{Study Limitations}

This study has several limitations. First, the fact that it is based on electronic hospital data constitutes the biggest limitation. Second, the decision of the physicians who performed the first triage of the patients affected the treatment method.

\section{Conclusions}

Emergency departments are an important part of hospitals. Some of the patients admitted to the emergency department experience urological emergencies. In this study, the emergency department doctors evaluate the patients, make the appropriate triage, and invite the urology doctor if necessary. Although the rate of urological cases in the emergency department was reported to be $15.6 \%$ in the literature, in our study, this rate was $0.39 \%$. Some of the urological emergencies can be diagnosed using simple tests, so a quick triage can be performed, and some of the cases can be relieved with simple interventions. The familiarity of the emergency department with these cases and the ability to perform some interventions can be life-saving and prevent the patient from developing unwanted future outcomes.

\section{Ethics}

Ethics Committee Approval: All procedures performed in this study involving human participants were in accordance with the ethical standards of the institutional and/or national research committee and with the 1964 Helsinki Declaration and its later 
amendments or comparable ethical standards. Zonguldak Bülent Ecevit University Local Ethic Committee (protocol number: 2019-203-18/2) approval is present.

Informed Consent: Informed written consent was obtained before oparation from all individual participants included in the study.

Peer-review: Externally peer-reviewed.

\section{Authors Contributions}

Concept: R.G., Design: R.G., Data Collection or Processing: K.E., Analysis or Interpretation: K.E., Literature Search: R.G., K.E., Writing: R.G.

Conflict of Interest: No conflict of interest was declared by the authors.

Financial Disclosure: The authors declared that this study received no financial support.

\section{References}

1. Topaktas R, Altın S, Aydın C, Akkoc A, Yılmaz Y. Retrospective evaluation of urological admissions to emergency service of a training and research hospital. Turk J Uro 2014;40:216-220.

2. Rifai $Z$, Ayub A. Urological emergencies-causes, symptoms and management. Hospital Pharmacist 2007;14:325-330.

3. Büyükcam $F$, Şen J, Akpınar Ş, Zengin $Y$, Çalık $M$, Odabaş Ö. Evaluation of urogenital injuries in patients with trauma at the emergency department. Ulus Travma Acil Cerrahi Derg 2012;18:133-140.

4. Dawson C, Whitfield H. ABC of Urology. Urological Emergencies in General Practice. BMJ 1996;312:838-840

5. Akıncı H. Analyses of Urological Emergencies in Karabuk State Hospital. Uludağ Tıp Derg 2009;35:17-20.

6. Palmer LS, Rosenbaum RR, Gershbaum MD, Kreutzer ER. Penetrating ureteral trauma at an urban trauma center: 10- year experience. Urology 1999;54:34-36.
7. Dimitrov TS, Udo EE, Emara M, Awni F, Passadilla R. Etiology and antibiotic susceptibility patterns of community-acquired urinary tract infections in a Kuwait hospital. Med Princ Pract 2004;13:334-339.

8. Matute $A J$, Hak E, Schurink CA, McArthur A, Alonso E, Paniagua M, Van Asbeck E, Roskott AM, Froeling F, Rozenberg-Arska M, Hoepelman IM. Resistance of uropathogens in symptomatic urinary tract infections in León, Nicaragua, Int J Antimicrob Agents 2004;23:506-509.

9. Mondet F, Chartier-Kastler E, Yonneau L, Bohin D, Barrou B, Richard F. Epidemiology of urological emergencies in a teaching hospital. Prog Urol 2002:12:437-442.

10. Shokeir AA. Renal colic: pathophysiology, diagnosis and treatment. Eur Urol 2001;39:241-249.

11. Cupisti A, Pasquali E, Lusso S, Carlino F, Orsitto E, Melandri R. Renal colic in Pisa emergency department: epidemiology, diagnostics and treatment patterns. Intern Emerg Med 2008;3:241-244.

12. Müslümanoğlu AY, Tepeler A. Renal kolik tanı ve tedavisi. Marmara Med Jour 2008;2:187-192.

13. Fall $B$, Diao B, Fall PA, Diallo $Y$, Sow $Y$, Ondongo AA, Diagana M, Ndoye AK, Ba $M$, Diagne BA. Urological emergencies at the Dakar university teaching hospital: epidemiological, clinical and therapeutic features. Prog Urol 2008;18:650-653.

14. Avellino GJ, Bose S, Wang DS. Diagnosis and Management of Hematuria. Surg Clin North Am 2016;96:503-515.

15. Hageman N, Aronsen T, Tiselius HG. A simple device (Hemostick) for the standardized description of macroscopic hematuria: our initial experience. Scand J Urol Nephrol 2006;40:149-154.

16. Demir Ö, Çelebi I, Esen A. Ürogenital sistemde acil yaklaşım gerektiren hastalıklar.In:Anafarta K,Arıkan N,Bedük Y(eds). Temel Üroloji Cep Kitabı. Güneş Kitabevi; 2008.690-98.

17. Kivioja AH, Myllynen PJ, Rokkanen PU. Is the treatment of the most severe multiply injured patients worth the effort? A follow-up examination 5 to 20 years after severe multiple injury. J Trauma 1990;30:480-483.

18. Ambani SN, Skupin P, Malaeb BS, Barboglio-Romo P, Stoffel JT. Does Early Ureteroneocystostomy After latrogenic Ureteral Injury Jeopardize Outcome? Urology 2020;136:245-250.

19. Baverstock $R$, Simons $R$, McLoughlin M. Severe blunt renal trauma: a 7-year retrospective review from a provincial trauma centre. Can J Urol 2001;8:1372-1376.

20. Rosenstein D, Mc Aninch JW. Urological emergencies. Med Clin North Am 2004;88:495-518. 